Jurnal Pendidikan Matematika : Judika Education

Volume 2, Nomor 2, Juli-Desember 2019

e-ISSN : 2614-6088

p-ISSN : 2620-732X

DOI: https://doi.org/10.31539/judika.v2i2.870

\title{
PENGEMBANGAN LKS BERBASIS PMRI MENGGUNAKAN KONTEKS ETNOMATEMATIKA PADA MATERI SPLDV
}

\author{
Rini Prabawati ${ }^{1}$, Yufitri Yanto $^{2}$, Novianti Mandasari ${ }^{3}$ \\ STKIP PGRI Lubuklinggau ${ }^{1,2,3}$ \\ riniprabawati20@gmail.com ${ }^{1}$
}

\begin{abstract}
ABSTRAK
Tujuan penelitian ini adalah untuk mengembangkan LKS berbasis Realistik menggunakan Konteks Etnomatematika pada materi SPLDV dan untuk mengetahui kualitas LKS dilihat dari aspek kevalidan dan kepraktisannya. Metode yang digunakan pada penelitian ini adalah metode Research and Depelopment $(R \& D)$ yang merupakan penelitian pengembangan mengacu pada model pengembangan 4-D, yaitu define, design, develop, dan disseminate yang di modifkasi menjadi 3-D. Instrumen yang digunakan untuk mengukur kualitas LKS yang dikembangkan meliputi lembar validasi, dan angket kepraktisan. Produk penelitian ini berupa LKS berbasis realistik menggunakan konteks etnomatematika pada materi SPLDV dengan saran siswa. Hasil penelitian menunjukkan bahwa: (1) kualitas LKS dilihat dari aspek kevalidan termasuk dalam kategori valid dengan skor rata-rata keseluruhan sebesar 3,06; dan (2) kualitas LKS dilihat dari aspek kepraktisan dikategorikan sangat praktis dengan skor rata-rata keseluruhan sebesar 3,5. Simpulan, pengembangan LKS berbasis PMRI dengan konteks Etnomatematika pada materi SPLDV dinyatakan valid dan praktis digunakan siswa.
\end{abstract}

Kata Kunci: LKS Etnomatematika, PMRI, SPLDV

\begin{abstract}
The purpose of this study was to develop a realistic worksheet using the Ethnomatematics on SPLDV material and to determine the quality of worksheets in terms of validity and practicality. The method used in this study is the Research and Dependency $(R \& D)$ method which is a developmental study referring to the 4-D development model, namely define, design, develop, and disseminate modified to 3-D. The instruments used to measure the quality of worksheets that were developed include validation sheets, and practicality questionnaires. The product of this research is a realistic worksheet using ethnomatematics context on SPLDV material with the advice of eighth grade students of junior high school. The results showed that: (1) the quality of worksheets seen from the validity aspects included in the valid category with an overall average score of 3.06; and (2) the quality of worksheets seen from the practical aspect is categorized very practical with an overall average score of 3.5. Conclusion, the development of PMRI-based worksheets in the context of ethnomatematics in SPLDV material was declared valid and practically used by students.
\end{abstract}

Keywords: Ethnomatematics worksheet, PMRI, SPLDV 


\section{PENDAHULUAN}

Pada saat ini pendidikan di Indonesia sudah menerapkan kurikulum 2013 (K13), begitu juga dengan sekolah yang ada di Lubuklinggau. K13 mendorong siswa untuk lebih aktif, kreatif, dan terampil sehingga pembelajaran akan menjadi lebih bermakna. Berdasarkan Permendikbud No 59 tahun 2014 kurikulum 2013 (K13) bertujuan mempersiapkan manusia di Indonesia agar dapat memiliki kemampuan hidup sebagai pribadi yang produktif, kreatif, inovatif, beriman, serta afektif dan mampu berkontribusi di kehidupan bermasyarakat, berbangsa, dan bernegara. Agar proses pembelajarannya dapat tercapai, dan siswa dapat memahami konsepkonsep yang dipelajarinya maka guru harus mampu mengembangkan bahan ajar yang dapat memudahkan siswa dalam memahami suatu konsep dan menyelesaikan masalah. Salah satu bahan ajar yang dapat dikembangkan yaitu LKS.

LKS mempunyai pengaruh yang besar dalam pembelajaran, LKS dapat mendorong proses berpikir siswa sehingga memudahkan siswa dalam menyelesaikan suatu masalah. Hal ini sejalan dengan pendapat Azhar (Rahmawati \& Marsigit, 2017), yang mengatakan bahwa LKS bertujuan untuk menuntun siswa serta menumbuhkan proses berpikir pada diri siswa. Dalam hal ini, LKS yang dimaksud adalah LKS matematika.

Matematika memiliki peran yang sangat penting dalam kehidupan sehari-hari, hampir semua yang ada di sekitar kita berkaitan dengan matematika termasuk juga dengan budaya masyarakat. Sehingga terlihat bahwa matematika sangat erat kaitannya dengan kehidupan seharihari dan budaya masyarakat. Hal ini sejalan dengan pendapat Hardiarti (2017), yang menyatakan bahwa matematika dan budaya merupakan sesuatu yang sering dijumpai dalam kehidupan sehari-hari dan tidak dapat dipisahkan, karena budaya adalah suatu kesatuan yang utuh serta menyeluruh, yang terdapat dalam suatu kehidupan masyarakat. Sedangkan matematika merupakan suatu pengetahuan yang digunakan dalam menyelesaikan masalah seharihari. Selanjutnya menurut Putri (2017), strategi untuk menciptakan lingkungan belajar dan pengalaman belajar yang mengintegrasikan budaya sebagai bagian dari proses pembelajaran yaitu pembelajaran berbasis budaya. Salah satunya dengan memanfaatkan pendekatan etnomatematika.

Kesulitan siswa dalam menghubungkan matematika dengan kehidupan nyata menjadikan faktor utama pentingnya pembelajaran berbasis budaya yaitu menggunakan pendekatan etnomatematika. Menurut Uloko \& Imoko (Astutiningtyas, et al. 2017), Negara Jepang dan Tionghoa berhasil karena mereka menerapkan etnomatematika dalam pembelajaran matematika. Etnomatematika digunakan untuk menjelaskan hubungan antara matematika dengan lingkungan budaya masyarakat.

Berdasarkan penilaian harian siswa mengenai materi SPLDV di SMP Ar-Risalah Lubuklinggau, banyak siswa yang tidak mencapai KKM yang telah ditetapkan di sekolah yaitu 60. Dari 30 siswa yang ada, 60\% siswa (18 siswa) yang belum mencapai KKM dengan nilai rata-ratanya 35 dan sisanya $40 \%$ 
siswa (12 siswa) mencapai KKM dengan nilai rata-rata yang didapat sebesar 75. Data diatas menunjukkan bahwa siswa mengalami kesulitan dalam belajar matematika.

Sehingga untuk mengatasi hal tersebut, dibutuhkan suatu pendekatan yang dapat menghubungkan konsep matematika dengan kehidupan seharihari dan membimbing siswa dalam menemukan konsep, yaitu dengan menggunakan pendekatan PMRI.

Hasil penelitian Friansyah (2018) pembelajaran menggunakan Pocket book dengan pendekatan PMRI mendapatkan kategori sangat baik. Pendekatan PMRI merupakan adaptasi dari pendekatan Realistic Mathematics Education (RME) yang dikembangkan di Belanda oleh Freudenthal. PMRI dapat memudahkan siswa dalam memahami konsep-konsep matematika dan menghubungkannya dengan kehidupan sehari-hari.

Hal ini sejalan dengan pendapat Pangestu \& Santi (2016), pendidikan matematika realistik dilaksanakan dengan menempatkan realitas dan pengalaman siswa yang digunakan sebagai titik awal pembelajaran, sehingga siswa diharapkan mampu menemukan dan merekonstruksi konsep-konsep matematika. Menurut Rahmawati \& Putri (2015), pembelajaran yang berdasarkan bahwa matematika harus dihubungkan secara nyata dengan konteks kehidupan sehari-hari yaitu dengan menggunakan PMRI.

Disamping itu hasil penelitian Handayani (2018) menyatakan Lembar Kerja Siswa yang dikembangkan memiliki efek potensial terhadap kemampuan penalaran matematika siswa
Hasil penelitian Adha (2019) Lembar Kerja Siswa yang dirancang menggunakan pendekatan matematika realistik Indonesia berbasis konteks Sumatera Selatan memiliki efek potensial terhadap hasil belajar siswa. Fokus penelitian ini adalah mengembangkan LKS Berbasis PMRI Menggunakan Konteks Etnomatematika pada Materi SPLDV yang valid dan praktis digunakan oleh siswa.

\section{METODE PENELITIAN \\ Pendekatan dan Metode Penelitian}

Peneliti menggunakan metode Research and Development (R\&D). Penelitian ini menghasilkan produk bahan ajar berupa LKS Berbasis PMRI Menggunakan Konteks Etnomatematika di Kota Lubuklinggau. Adapun desain dan pengembangan LKS menggunakan model pengembangan 4-D four $D$ model) yang dimodifikasi menjadi 3D yang terdiri atas 3 tahapan yaitu: Pendefinisian (define), Perancangan (design), dan Pengembangan (develop). Prosedur yang dilakukan dalam penelitian ini adalah sebagai berikut:

\section{Tahap Pendefinisian (Define)}

Tahap ini memiliki 5 langkah utama yaitu analisis awal akhir, analisis siswa, analisis tugas dan analisis konsep serta perumusan tujuan pembelajaran.

\section{Analisis Awal Akhir}

Analisis awal akhir bertujuan untuk menentukan masalah yang dialami dalam pembelajaran. Tahap ini dilakukan dengan melakukan observasi dan wawancara pada salah satu guru matematika di SMP Ar- 
Risalah Lubuklinggau terhadap pembelajaran materi SPLDV.

\section{Analisis siswa}

Analisis siswa bertujuan untuk mengetahui karakteristik siswa yang sesuai dengan rancangan dan perangkat pembelajaran yang dikembangkan.

\section{Analisis Tugas}

Analisis tugas bertujuan untuk dapat merincikan isi materi ajar dalam bentuk garis besar.

\section{Analisis Konsep}

Analisis konsep bertujuan untuk mengidentifikasi konsepkonsep yang diajarkan, serta menyusunnya secara sistematis sehingga membentuk suatu peta konsep.

\section{Perumusan Tujuan Pembelajaran}

Perumusan

tujuan

pembelajaran, dilakukan untuk menetapkan tujuan pembelajaran yang didasarkan pada Kompetensi Dasar (KD) dan indikatornya.

\section{Tahap Perancangan (Design)}

Tahap ini bertujuan untuk menyiapkan prototipe perangkat pembelajaran. Tahap ini terdiri dari pemilihan media, pemilihan format, dan desain awal.

\section{Tahap Pengembangan (Develop)}

Tahap develop (mengembangkan) bertujuan untuk menghasilkan perangkat pembelajaran yang telah direvisi berdasarkan masukan dari pakar.

\section{HASIL PENELITIAN}

Pengembangan LKS berbasis PMRI menggunakan konteks etnomatematika di Kota Lubuklinggau ini dikembangkan dengan menggunakan model pengembangan 4D yang dilakukan dengan menggunakan tiga tahapan, yaitu tahap Define (pendefinisian), Design (perancangan), dan Develop (pengembangan). Tahap-tahap tersebut dilakukan dengan tujuan untuk menghasilkan LKS yang valid dan praktis.

Pada tahap define, tahapan awal pengembangan LKS dilakukan dengan melakukan wawancara terhadap guru mata pelajaran matematika di SMP Ar-Risalah Lubuklinggau untuk mendapatkan data yang diperlukan untuk analisis awal akhir, analisis siswa, analisis tugas, analisis konsep, dan perumusan tujuan pembelajaran. Pada analisi awal akhir permasalahan yang timbul dalam pembelajaran matematika yaitu siswa kurang terlibat dalam proses pembelajaran karena pembelajaran hanya terfokus pada guru, materi sistem persamaan linear dua variabel adalah materi yang bersifat abstrak sehingga siswa tidak dapat memahami permasalahan dengan baik, siswa belum terampil dalam menyelesaikan, menelaah atau mengkaji permasalahan berupa soal cerita, proses belajar siswa di dalam kelas hanya mendengar penjelasan dari guru.

Pada analisis siswa diperoleh siswa SMP Ar-Risalah Lubuklinggau memiliki kemampuan yang merata yaitu tinggi, sedang, dan rendah, tingkat perkembangan kognitif siswanya belum mampu untuk berfikir abstrak dan logis, hal ini 
dapat dilihat dari hasil ulangan harian siswa mengenai materi SPLDV di SMP Ar-Risalah Lubuklinggau, banyak siswa yang tidak mencapai KKM. Dari 30 siswa yang ada, 60\% siswa (18 siswa) yang belum mencapai KKM dengan nilai rataratanya 35 dan sisanya $40 \%$ siswa (12 siswa) mencapai KKM dengan nilai rata-rata yang didapat sebesar 75 . Pada analisis tugas, garis besar materi LKS ini meliputi: (1) permasalahan danlangkah-langkah penyelesaiannya, (2) latihan, (3) kesimpulan. Pada analisis konsep menghasilan suatu peta konsep materi SPLDV. Pada perumusan tujuan pembelajaran menghasilkan indikator pencapaian hasil belajar yang akan dicapai oleh siswa.

Tahap selanjutnya adalah tahap perancangan (design). Langkah pertama yang dilakukan yaitu menyusun tes acuan patokan, berupa soal-soal cerita yang sering dijumpai siswa dalam kehidupan sehari-hari. Langkah selanjutnya yaitu pemilihan media, dalam penelitian ini LKS dipilih sebagai media atau sarana untuk menyampaikan materi pembelajaran. Selanjutnya pemilihan format, format LKS yang dipilih adalah format LKS berbasis PMRI menggunakan konteks etnomatematika di kota Lubuklinggau dan materi yang termuat dalam LKS sesuai dengan kompetensi dasar 3.5 dan 4.5 kurikulum 2013 tentang SPLDV.

Langkah selanjutnya yaitu desain awal, kegiatan pada tahap ini yaitu penulisan rancangan awal perangkat pembelajaran yang dikembangkan yaitu berupa LKS berbasis PMRI menggunakan konteks etnomatematika di kota Lubuklinggau dan pembuatan instrumen penelitian. LKS ini dikembangkan dengan menggunakan aplikasi Microsoft Office Word 2003. Pada tahap pembuatan instrumen penelitian, peneliti membuat instrumen penilaian kevalidan LKS berupa angket ahli dan penilaian kepraktisan berupa angket kepraktisan siswa dan guru.

Tahap selanjutnya yaitu tahap pengembangan (develop). LKS yang dikembangkan kemudian divalidasi oleh dosen ahli bahasa, ahli materi, dan ahli media lalu direvisi sesuai dengan saran para ahli. Setelah direvisi, LKS kemudian diuji kepraktisan terhadap guru lalu direvisi sesuai dengan saran, setelah itu LKS diujicobakan yaitu dengan ujicoba kelompok kecil (small group), terdiri dari 6 siswa dengan kemampuan yang heterogen kemudian direvisi setelah itu diujicobakan lagi terhadap kelompok besar dengan jumlah siswa seperti pada kelas yang sesungguhnya.

\section{PEMBAHASAN}

Berdasarkan hasil penelitian pengembangan, dihasilkan LKS berbasis PMRI menggunakan konteks etnomatematika di kota Lubuklinggau. Penelitian ini bertujuan untuk mengetahui tingkat kevalidan dan kepraktisan LKS pada materi SPLDV. Berdasarkan hasil keseluruhan penilaian kevalidan LKS dari tiga validator terhadap LKS yang dikembangkan, menunjukkan bahwa LKS yang dikembangkan termasuk dalam kategori valid dengan skor rata-rata keseluruhan sebesar 3,06 dan dapat diujicobakan ketahap selanjutnya. Setelah dinyatakan valid, kemudian LKS diujicoba tingkat kepraktisannya terhadap guru dan 
siswa. Berdasarkan hasil ujicoba terhadap kelompok kecil dengan jumlah 6 siswa yang dipilih secara heterogen, ujicoba kelompok besar dengan jumlah 30 siswa di SMP ArRisalah Lubuklinggau, dan uji kepraktisan LKS terhadap guru menghasilkan respon yang positif. Berdasarkan hasil angket respon siswa yang telah diberikan, siswa merasa senang dan tertarik untuk belajar menggunakan LKS yang telah dikembangkan. Berdasarkan hasil keseluruhan penilaian data angket kepraktisan siswa dan guru, diperoleh rata-rata skor sebesar 3,5 dan berkategori sangat praktis. Sehingga dari hasil yang diperoleh, LKS yang dikembangkan dapat digunakan dengan baik tanpa ada kendala.

\section{SIMPULAN}

Lembar Kerja Siswa yang dikembangkan dikategorikan valid dan sangat praktis dan dapat dijadikan sebagai salah satu alternatif penunjang kegiatan pembelajaran matematika pada materi SPLDV.

\section{DAFTAR PUSTAKA}

Adha, I., \& Refianti, R. (2019). Pengembangan Lembar Kerja Siswa (LKS) Menggunakan Pendekatan Matematika Realistik Indonesia Berbasis Konteks Sumatera Selatan. Jurnal Pendidikan Matematika (JUDIKA EDUCATION), 2(1), $1-10$.

https://doi.org/https://doi.org/10 .31539/judika.v2i1.729

Astutiningtyas, E., Wulandari, A. \& Farahsanti, I. (2017). Etnomatematika \& Pemecahan Masalah Kombinatorik. Jurnal
Math Educator Nusantara (JMEN), 3 (2); 110-134.

Friansah, D., Adha, I., \& Refianti, R. (2018). Pengembangkan Pocket Book Berbasis Pendekatan Matematika Realistik Indonesia (PMRI) Materi Bangun Ruang Sisi Datar. Jurnal Pendidikan Matematika (JUDIKA EDUCATION), 1(1), 1-11. https://doi.org/https://doi.org/10 .31539/judika.v1i1.243

Handayani, S., \& Mandasari, N. (2018). Pengembangan Lembar Kerja Siswa (LKS) Berbasis Problem Based Learning untuk Meningkatkan Kemampuan Penalaran Matematika. Jurnal Pendidikan Matematika (Judika Education), 1(2), 144-151. https://doi.org/https://doi.org/10 .31539/judika.v1i2.412

Hardiarti. (2017). Etnomatematika: Aplikasi Bangun Datar Segiempat pada Candi Muaro Jambi. Aksioma, 8 (2); 99-110.

Pangestu \& Santi. (2016). Pengaruh Pendidikan Matematika Realistik Terhadap Suasana Pembelajaran yang Menyenangkan pada Pelajaran Matematika Sekolah Dasar. FIBONACCI Jurnal Pendidikan Matematika \& Matematika, 2 (2); 55-68.

Peraturan Pemerintah. (2014). Peraturan Menteri Pendidikan dan Budaya Republik Indoneia No 59 Tahun 2014 Kurikulum 2013 (K13). Jakarta:Mendikbud.

Putri. (2017). Eksplorasi Etnomatematika Kesenian Rebana Sebagai Sumber Belajar Matematika Pada Jenjang MI. 
Jurnal Ilmiah "PENDIDIKAN DASAR", 4 (1); 20-32.

Rahmawati \& Marsigit. (2017). Pengembangan Bahan Ajar Berbasis Etnomatematika untuk Meningkatkan Prestasi dan Motivasi Belajar Siswa SMP. Jurnal Pendidikan Matematika, $6(6) ; 65,-77$.

Rahmawati \& Putri. (2015).

Keefektifan Pembelajaran

Dengan Pendekatan Pendidikan

Matematika Realistik (Pmri)

Pada Kemampuan Pemecahan

Masalah Pokok Bahasan

Segiempat Di Mts Negeri 1

Palembang. Jurnal Pendidikan

Matematika JPM RAF, 1(1); 2-

15. 